\title{
Comparison of five different methods of rubella IgM antibody testing
}

\author{
HEATHER CUBIE, ELIZABETH EDMOND \\ From the Regional Virus Laboratory, Edinburgh, and the Department of Bacteriology, University of \\ Edinburgh, Edinburgh
}

SUMMARY Five tests for the detection of rubella specific IgM antibody were compared. They were the conventional method of sucrose density gradient fractionation, followed by haemagglutination inhibition; an anti- $\mu$ capture radioimmunoassay; and three commercially available enzyme linked assays: Rubazyme M, Rubenz M I, and its successor, Rubenz M II. The five methods detected similar numbers of rubella positive samples between seven and 35 days after the onset of symptoms; in the earlier stages, however, the radioimmunoassay and Rubenz $\mathrm{M}$ II were more sensitive. All three commercial kits were straightforward to use but produced misleading positive results with sera containing heterophil antibody. In considering sensitivity, specificity, and cost effectiveness together the Rubenz $M$ tests were the most appropriate for routine use. With the recent withdrawal of Rubenz M I from the market only Rubenz M II is now available. If Epstein-Barr virus infection is excluded, Rubenz M II provides a reliable test for the diagnostic laboratory.

The diagnostic virology laboratory has a wide and possibly confusing choice of tests for rubella specific macroglobulin (IgM). We have attempted to compare in parallel the specificity, sensitivity, and ease of use of five methods.

\section{Material and methods}

The methods available were: sucrose density gradient fractionation followed by haemagglutination inhibition (SDGHAI); a radioimmunoassay; the MACRIA (the antirubella monoclonal antibodies and standard sera were supplied by Dr RS Tedder); an indirect immunoassay Rubazyme $M$ (Abbot Laboratories Ltd); and two enzyme linked $\mu$-chain capture methods Rubenz M (Northumbria Biologicals Ltd).

SDGHAI was performed using standard procedures as described by Cubie.'

The details of the MACRIA test have been published elsewhere. ${ }^{2}$ The test was modified by the use of Iodine-125 labelled monoclonal antirubella antibody. ${ }^{3}$ Rubella antigen for this test was kindly supplied by the reagent division of the Public Health

Accepted for publication 22 October 1984
Laboratory Service. The standard sera containing 100,10 , and 3.3 arbitary units (au) of IgM antibody were included in each test run and a standard graph was drawn from which the results of the test sera were read. Sera containing 3.3 au or more activity were considered positive.

Rubazyme $\mathbf{M}$, which incorporates an absorption step for the removal of antiglobulin factors, was applied as directed by the manufacturers. Results were calculated in terms of Rubazyme $\mathbf{M}$ indices $\left(\mathrm{RI}_{\mathrm{m}}\right)$ by dividing the absorbance of the sample at $492 \mathrm{~nm}$ by the mean absorbance of low positive control samples tested in triplicate. Results greater than 1.090 were considered positive and those of less than 0.910 negative. Results between these readings were considered to be equivocal.

Rubenz M I and II are $\mu$-chain capture techniques in which rubella antigen, bound by immobilised IgM, is traced by enzyme labelled monoclonal antibody to rubella. Both were used exactly as directed. Sera were tested against viral and control antigens and the absorbance of the control well was subtracted from the absorbance of the test well to give a corrected value. In both tests any serum giving a corrected absorbance value equal to or greater than the 5 unit standard included in the kit was considered positive. In the Rubenz $M$ II test the chromogenic substrate $3,3^{\prime}, 5,5^{\prime}$ tetramethyl ben- 
Table 1 Results of testing non-rubella serum for rubella specific IgM by five methods

\begin{tabular}{|c|c|c|c|c|c|c|}
\hline \multirow[t]{2}{*}{ Samples from patients with } & \multirow{2}{*}{$\begin{array}{l}\text { Total no of } \\
\text { samples available }\end{array}$} & \multicolumn{5}{|c|}{ No positive (no tested) } \\
\hline & & $\overline{S D G H A I}$ & $M A C R I A$ & Rubazyme $M$ & Rubenz MI & Rubenz M II \\
\hline $\begin{array}{l}\text { Other viral infections } \\
\text { Epstein-Barr virus infection } \\
\text { Rheumatoid factor present }\end{array}$ & $\begin{array}{l}18 \\
18 \\
13\end{array}$ & $\begin{array}{l}0(14) \\
0(12) \\
0(13)\end{array}$ & $\begin{array}{l}0(18) \\
0(18) \\
0(13)\end{array}$ & $\begin{array}{l}0(18) \\
2 P, 2 E(18) \\
1 P 2 E(13)\end{array}$ & $\begin{array}{l}0(18) \\
2 P(18) \\
0(13)\end{array}$ & $\begin{array}{l}0(12) \\
6(17)^{*} \\
0(12)\end{array}$ \\
\hline
\end{tabular}

$P=$ positive; $E$ = equivocal.

*3/15 positive with the most recent Rubenz M II kit (see text).

zidine is used in place of the o-phenylenediamine used in Rubenz M I.

\section{SERUM SAMPLES}

One hundred and thirty samples were available for testing by the five methods. Eighty one samples had been submitted from 37 patients in whom rubella infection had been previously -onfidently diagnosed by the demonstration of a rising or high stable haemagglutination inhibition titre along with the presence of specific IgM by SDGHAI in at least one specimen. Thirty two patients had clinical symptoms suggesting rubella infection, and five were pregnant women who had been in close contact with rubella early in pregnancy but had developed no rubella like symptoms.

Thirty six samples were from patients with laboratory confirmed recent viral infections other than rubella. Eighteen samples were from patients with Epstein-Barr virus infection, and the remainder were from patients suffering from a variety of infections including mumps, measles, cytomegalovirus, hepatitis A, Mycoplasma pneumoniae and Toxoplasma gondii.

Thirteen samples from 13 different patients were selected for testing because they contained known titres of rheumatoid factor and rubella specific IgG.

\section{Results}

The time consuming and labour intensive nature, with resulting high cost, of the SDGHAI is familiar to most diagnostic laboratories. The MACRIA test was easier to perform but also required expensive equipment and more stringent safety controls. In comparison, all of the commercial kits were simple to use and the only test which could be completed in a single day was the Rubazyme $\mathbf{M}$. Both Rubenz $\mathbf{M}$ tests, however, were considerably cheaper.

Table 1 suggests that in this series MACRIA and SDGHAI were the most specific for rubella IgM, although only 39 samples could be tested by SDGHAI because of the small volume available. Epstein-Barr virus infections produced misleading positive results in all three commercial kits; the highest number (six of 17 tested) occurred with the Rubenz M II test. Early Rubenz M II kits produced little reaction colour with the positive control samples. At that time the manufacturer's instructions stated that the reaction product was unstable and that absorbancies should be read immediately on stopping. Indeed, we found that fading occurred so rapidly that low positives could become negative.

Retesting of 15 of the Epstein-Barr virus IgM positive samples with the most recent Rubenz M II test gave only three clearly positive results in the presence of much stronger colour in the positive controls. Rubazyme $\mathbf{M}$ was the only test to give equivocal or positive results in samples containing rheumatoid factor.

The results of testing 81 samples from patients thought to have had recent rubella infection are shown in Table 2. Although SDGHAI, MACRIA, and Rubenz $M$ II detected more positive results overall, there was some disagreement among the three tests, with 11 samples giving discrepant

Table 2 Results of testing sera from patients previously diagnosed as having recent rubella

\begin{tabular}{|c|c|c|c|c|c|c|c|c|c|c|c|c|c|}
\hline \multirow[t]{2}{*}{ Patient group } & \multirow{2}{*}{$\begin{array}{l}\text { No of } \\
\text { patients }\end{array}$} & \multirow{2}{*}{$\begin{array}{l}\text { No of } \\
\text { specimens }\end{array}$} & \multicolumn{2}{|c|}{ SDGHAI } & \multicolumn{2}{|c|}{$M A C R I A$} & \multicolumn{3}{|c|}{ Rubazyme $M$} & \multicolumn{2}{|c|}{ Rubenz MI } & \multicolumn{2}{|c|}{ Rubenz MII } \\
\hline & & & + & - & + & - & + & $E$ & - & + & - & + & - \\
\hline Rising haemagglutination inhibition titre & 30 & 65 & 46 & 19 & 50 & 15 & 39 & 3 & 23 & 40 & 23 & 48 & 16 \\
\hline $\begin{array}{l}\text { High stable haemaggiutination inhibition } \\
\text { titre with IgM } \\
\text { Total }\end{array}$ & $\begin{array}{r}7 \\
37\end{array}$ & $\begin{array}{l}16 \\
81\end{array}$ & $\begin{array}{l}14 \\
60\end{array}$ & 21 & $\begin{array}{l}11 \\
61\end{array}$ & $\begin{array}{r}5 \\
20\end{array}$ & $\begin{array}{l}10 \\
49\end{array}$ & $\begin{array}{l}1 \\
4\end{array}$ & $\begin{array}{r}5 \\
28\end{array}$ & $\begin{array}{l}10 \\
50\end{array}$ & $\begin{array}{r}6 \\
29\end{array}$ & $\begin{array}{l}13 \\
61\end{array}$ & $\begin{array}{r}3 \\
19\end{array}$ \\
\hline
\end{tabular}

$\mathrm{E}=$ equivocal. 
Table 3 Comparison of methods related to time of onset of symptoms of rubella when known

\begin{tabular}{|c|c|c|c|c|c|c|}
\hline \multirow[t]{2}{*}{ Days after onset } & \multirow[t]{2}{*}{ No of specimens } & \multicolumn{5}{|c|}{ No of specimens positive } \\
\hline & & $S D G H A I$ & $M A C R I A$ & Rubazyme $M$ & Rubenz MI & Rubenz M II \\
\hline $\begin{array}{c}0-2 \\
3-4 \\
5-8 \\
9-10 \\
11-35 \\
36-40\end{array}$ & $\begin{array}{r}9 \\
10 \\
8 \\
8 \\
20 \\
3\end{array}$ & $\begin{array}{r}3 \\
7 \\
7 \\
7 \\
20 \\
1\end{array}$ & $\begin{array}{r}3 \\
7 \\
8 \\
8 \\
20 \\
1\end{array}$ & $\begin{array}{rl}2+, 1 \mathrm{E} \\
6 & \\
7 & \\
8 & \\
20 & \\
0 & 1 \mathrm{E}\end{array}$ & $\begin{array}{r}3 \\
5 \\
7 \\
6 \\
20 \\
2\end{array}$ & $\begin{array}{r}5 \\
6 \\
7 \\
8 \\
20 \\
2\end{array}$ \\
\hline
\end{tabular}

$+=$ positive; $E$ = equivocal.

results. SDGHAI and MACRIA agreed in three, MACRIA and Rubenz M II in three, and SDGHAI and Rubenz $M$ II in five. Rubazyme $M$ and Rubenz $M$ I detected fewer positive samples than the other methods. Although the numbers of positive samples were similar, there were also several discrepancies between these two methods.

Early after the onset of rubella like symptoms (0-2 days, Table 3 ) IgM was detected by at least one method in $5 / 9$ specimens. The five were all positive by Rubenz M II. Only one serum taken at this time was positive by all five methods. MACRIA and SDGHAI detected the most positives in specimens submitted three to four days after the onset of symptoms. All but three samples taken between five and 10 days after onset of symptoms were positive for IgM by all methods. One specimen, taken from a 17 year old boy eight days after the onset of rubella, was positive only by MACRIA. Twenty seven days later a second specimen from the same patient was positive by all methods. Another specimen from a second patient was positive by four methods but negative by Rubenz M I. This was a second specimen from a patient whose first serum sample, taken three days after the onset of symptoms, was positive by SDGHAI and MACRIA but negative by Rubazyme $M$ and Rubenze $M$ I and II. The third specimen giving discordant results at this time was taken from a patient 10 days after his rash appeared: both SDGHAI and Rubenz M I were negative while
MACRIA, Rubazyme M, and Rubenz M II were positive. Again a specimen from the same patient taken three days later was positive in all four tests. All specimens taken between 11 and 35 days after the onset of symptoms were positive by all methods tested.

The patient whose detailed results are shown in Table 4 had had an apparently successful rubella vaccination two years before her reported contact. She was in early pregnancy when her daughter developed clinical rubella. IgM was detected by MACRIA in all three specimens and by SDGHAI and Rubenz M II in two specimens.

\section{Discussion}

Many new techniques for detecting rubella specific IgM have been described in the past few years. Some have been developed empirically in individual laboratories, ${ }^{2-6}$ while others are freely available in kit form from commercial sources. Some reports of comparisons between methods have already been published.. ${ }^{1-11}$

Although we tested only a small number of samples (and no cord samples) by all five methods, several important messages emerge from the analysis of our results. All three commercial kits gave apparently false positive results in samples taken from patients who did not have rubella. All samples giving these apparently false positive results

Table 4 Quantitative rubella specific IgM in previously vaccinated contact of rubella

\begin{tabular}{|c|c|c|c|c|c|c|c|}
\hline Days past contact & $S R H$ & $\begin{array}{l}\text { Haemagglutination } \\
\text { inhibition }\end{array}$ & $S D G H A I$ & $\underset{(a u)}{M A C R I A}$ & $\begin{array}{l}\text { Rubazyme } M \\
\left(R I_{m}\right)\end{array}$ & Rubenz $M I^{*}$ & Rubenz $M I^{*}$ \\
\hline $\begin{array}{l}6 \text { weeks post vacc } \\
0 \\
-21 \\
+25\end{array}$ & $\begin{array}{l}\text { NT } \\
(+) \\
++ \\
+\end{array}$ & $\begin{array}{l}256 \\
16 \\
1024 \\
1024\end{array}$ & $\begin{array}{l}\text { NT } \\
\text { Negative } \\
\text { Weak positive } \\
\text { Positive }\end{array}$ & $\begin{array}{l}\text { NT } \\
3 \cdot 16 \\
14 \cdot 45 \\
\text { NT }\end{array}$ & $\begin{array}{l}\text { NT } \\
0.39 \\
0.62 \\
0.65\end{array}$ & $\begin{array}{l}\text { NT } \\
0.38 \\
\text { NT } \\
0.06\end{array}$ & $\begin{array}{l}\text { NT } \\
0.04 \\
11.6 \\
11.8\end{array}$ \\
\hline
\end{tabular}

$(+)=$ positive but less than 15 is standard.

NT $=$ not tested.

*In view of the wide variation in absorbancies of the low positive control provided with Rubenz kits during different runs the result has been expressed numerically as: the difference in absorbancy between viral and control antigen for test serum divided by difference in absorbancy between viral and control antigen for low positive control.

Values greater than 1 have been taken as positive. 
contained both heterophil antibody and EpsteinBarr virus IgM. Some also contained rheumatoid factor. Similar problems have already been reported with Rubazyme $\mathbf{M}^{11011}$ and also with MACRIA. ${ }^{1011}$ In contrast Hodgson and Morgan-Capner ${ }^{7}$ reported no positive results with Rubenz $\mathrm{M}$ I when testing a series of 10 serum samples from patients with infectious mononucleosis, including seven known to give positive results with MACRIA. False positive results with MACRIA were not obvious in the series we tested, probably because we tested with Judith antigen a limited number of samples and considered negative any reading less than 3.3 au. The positive results obtained with samples from patients with Epstein-Barr virus infection may be due to a sensitive test detecting minimal quantit'es of rubella IgM produced by the polyclonal activation of B lymphocytes, which is the hallmark of infectious mononucleosis. ${ }^{10}$ Nevertheless, it is a misleading result for the clinician attempting to make a laboratory diagnosis of rubella and any sample giving positive results must be tested for Epstein-Barr virus IgM and heterophil antibody before a diagnosis of rubella can be made.

False positive results due to interference by rheumatoid factor occurred when some sera were tested with Rubazyme M. Any serum found positive in this test would therefore require to be tested for rheumatoid factor and if positive retested after absorption with $\gamma$ globulin. Although theoretically the presence of rheumatoid factor might cause interference in $\mu$-chain capture assays, ${ }^{6}$ this was not a problem in our hands.

When samples from patients with previously diagnosed rubella were retested with the new methods not all specimens were positive by all tests until 11 days after the onset of disease. In the first two days of illness Rubenz M II detected more positive results than any other test. Between zero and eight days after onset, Rubenz M II and MACRIA detected $18 / 27(67 \%)$ of positive specimens, SDGHAI detected 17, and Rubazyme $M$ and Rubenz M I were the least sensitive (15/27). All specimens collected five days or more after the onset of illness were positive by MACRIA as previously reported by Mortimer et al. ${ }^{2}$

Therefore, when well timed samples can be taken from patients with clinical symptoms of rubella any one of the tests investigated in this study could be used to confirm the diagnosis. Tests based on $\mu$-chain capture (MACRIA, Rubenz M I and Rubenz M II) have an advantage over Rubazyme $M$ in that they are not affected by the presence of rheumatoid factor. Rubenz $\mathrm{M}$ II is the simplest to perform and offers greater sensitivity than Rubenz M I, but this also appears to increase the positive results in samples from patients with infectious 을 mononucleosis.

We present here a patient who, after successful vaccination two years previously, produced rubella IgM during a natural asymptomatic reinfection in early pregnancy. Cradock-Watson et $^{1 l^{12}}$ noted similar results in serum from a woman who developed low concentrations of IgM three years after vaccina- $\$$ tion following close contact with rubella at seven $\overrightarrow{0}$ months of pregnancy. We believe that such women represent an important problem of management, $\vec{\omega}$ which will increase in future epidemics when vaccine induced immunity may, in a few individuals, have ? fallen to low levels ${ }^{1314}$ and when sensitive and con- $\omega_{\infty}$ venient methods for IgM testing are widely avail- i able. ${ }^{15}$ If an IgM response in reinfection is ever $\tilde{O}$ associated with viraemia, and there is both experimental $^{16}$ and clinical evidence ${ }^{17-19}$ that this may occur, then the fetuses of these women may be at $\vec{T}$ risk. This potential risk to the fetus would not have $\mathbb{D}$ been recognised by the use of either Rubazyme $M$ or Rubenz M I.

It is likely, however, that the use of a sensitive $\mu$-chain capture technique allows the detection of $\varnothing_{\infty}$ IgM antibody to a wider range of rubella epitopes (including non-neutralising epitopes) than the standard SDGHAI technique. High concentrations of IgM will occur in reinfection only in the individual who does not retain adequate concentrations of antibodies directed against epitopes essential for $\stackrel{\mathbb{Q}}{\Omega}$ virus neutralisation in vivo. Obviously the qualita- $\overrightarrow{\vec{P}}$ tive nature of the humoral response after natural $\frac{\circ}{3}$ and induced rubella infection requires much more $\bar{\partial}$ detailed investigation..$^{20}$ In practice, however, the presence of even small amounts of IgG taken shortly after contact, along with the kinetics of the total? antibody response, should be given more emphasis $\frac{5}{3}$ than the finding of a single low concentration of IgM in a sensitive assay.

MACRIA and Rubenz M II were the most sensitive overall in this study. As a result, Rubenz M II is $ᄋ$ the method of choice in this routine diagnostic $>$ laboratory, with SDGHAI remaining as a valuable confirmatory method. Particular emphasis is given to the exclusion of infection with Epstein-Barr virus."

This work was supported by a generous grant from the Scottish Home and Health Department. We would like to thank Alison Frew, Jean Fleetwood, and Ian Collacott for expert technical assistance.

\section{References}

1 Cubie HA. Evaluation of a new ELISA method for estimating $\frac{\Omega}{\mathscr{Q}}$ rubella specific IgM antibody. $J$ Infect 1983;7:144-50.

${ }^{2}$ Mortimer PP, Tedder RS, Hambling MW, Shafi MS, Burkhardt㝏 
F, Schult U. Antibody capture immunoassay for antirubella IgM. J Hyg 1981;86:139-53.

${ }^{3}$ Tedder RS, Yao J, Anderson MJ. The production of monoclonal antibodies to rubella haemagglutinin and their use in antibody-capture assays for rubella-specific IgM. J Hyg 1982;88:335-50.

4 Krech U, Wilhelm JA. A solid-phase immunosorbent technique for the rapid detection of rubella IgM by haemagglutination inhibition. J Gen Virol 1979;44:281-6.

s Braun R, Doerr MW, Geisen HP, Hornig C, Hushka E, Munk K. Comparison of different methods for the detection of rubellaspecific IgM antibodies. J Med Virol 1981;8:207-14.

- Kurtz JB, Malic A. Rubella-specific IgM detected by an antibody capture assay/ELISA technique. J Clin Pathol 1981;34: 1392-5.

${ }^{7}$ Hodgson J, Morgan-Capner P. Evaluation of a commercial antibody capture enzyme immunoassay for the detection of rubella specific IgM. J Clin Pathol 1984;37:573-7.

" Cradock-Watson JE, Ridehalgh MKS, Pattison JR, Anderson MJ, Kangro HO. Comparison of immunofluorescence and radioimmunoassay for detecting IgM antibody in infants with the congenital rubella syndrome. J Hyg 1979;83:413-23.

- Mertens T, Zippel C, Senffler R, Eggers H. Comparison of four different methods for detection of rubella IgM antibodies. Med Microbiol Immunol 1983; 172:181-9.

${ }^{10}$ Morgan-Capner P, Tedder RS, Mace JE. Rubella-specific IgM reactivity in sera from cases of infectious mononucleosis. J Hyg 1983;90:407-13.

" Best JM, Palmer SJ, Morgan-Capner P, Hodgson J. A comparison of Rubazyme-M and MACRIA for the detection of rubella specific IgM. J Virol Methods 1984;8:99-109.
$1 /$ Cradock-Watson JE, Risehalgh MKS, Anderson MJ, Pattison JR. Outcome of asymptomatic infection in rubella virus during pregnancy. J Hyg 1981;87:147-54.

13 Zealley H, Edmond E. Rubella screening and immunisation of schoolgirls: results six to seven years after vaccination. $\mathrm{Br}$ Med J 1982; 284: 382-4.

14 Banatvala JE, Best JM, O'Shea S. Strategy for rubella vaccination. Lancet $1981 ; \mathrm{i}: 251$.

is Mortimer PP, Tedder RS. Screening for anti-rubella IgM ad libitum. J Hyg 1983;90: 1-5.

${ }^{16}$ Balfour HH, Groth KE, Edelman CK, Amren DP, Best JM, Banatvala JE. Rubella viraemia and antibody responses after rubella vaccination and reimmunisation. Lancet 1981;i: 1078-80.

${ }^{17}$ Partridge JW, Flewett TH, Whitehead JEM. Congenital rubella affecting an infant whose mother had rubella antibodies before conception. Br Med J 1981;282:187-8.

${ }_{18}$ Best JM, Harcourt GC, Banatvala JE, Flewett TH. Br Med J 1981;282:413-23.

${ }^{14}$ Morgan Capner P, Hodgson J, Sellwod J, Tippett S. Clinically apparent rubella reinfection. $J$ Inf 1984;9:97-101.

${ }^{20}$ Ho-Terry L, Cohen A, Tedder RS. Immunological characterisation of rubella virion polypeptides. J Med Microbiol 1984; 17:105-9.

Requests for reprints to: Dr Elizabeth Edmond, Department of Bacteriology, University Medical School, Teviot Place, Edinburgh EH8 9AG, Scotland. 